\title{
BIMBINGAN DAN PELATIHAN IMPLEMENTASI KEPEMIMPINAN UNTUK PEMBERDAYAAN IBU-IBU PKK RW 03 KELURAHAN KETAWANG GEDE KOTA MALANG
}

\author{
Masreviastuti ${ }^{1}$, Mahmudatul Himmah ${ }^{2}$, Helmy Adisaksana ${ }^{3}$, Lilies Nur Aini ${ }^{4}$, Fauziah $^{4}$ \\ $1,2,3,4,5$ Jurusan Administrasi Niaga, Politeknik Negeri Malang
}

\begin{abstract}
Abstrak
To create harmonious living conditions, group members must respect and appreciate each other. Humans are endowed with the ability to think, the ability to sort \& choose what is good \& what is bad. With these advantages, humans should be able to manage the environment well. Not only should the environment be managed properly, human social life also needs to be managed properly. For that we need quality human resources. A resource with a leadership spirit, at least to lead himself. In RW 03, Ketawang Gede Village, the number of PKK members consists of 30 mothers with 90\% professions: entrepreneurs, 10\% private employees and civil servants aged between 25 - 50 years where they always need to do independent and team work.

With the spirit of a human leader, he will be able to manage himself, the group \& the environment well. Especially in dealing with problems that are relatively complicated \& difficult, so a leader is required to be wise in making decisions so that problems can be resolved properly.
\end{abstract}

Keywords - Leadership, Type of Leadership, Human Resources

\section{PENDAHULUAN}

$\mathrm{M}$ anusia adalah makhluk social yang tidak dapat hidup sendiri. Dalam hidup, manusia selalau berinteraksi dengan sesama serta dengan lingkungan. Manusia hidup berkelompok baik dalam kelompok besar maupun dalam kelompok kecil. Hidup dalam kelompok tentulah tidak mudah. Untuk menciptakan kondisi kehidupan yang harmonis anggota kelompok haruslah saling menghormati \& menghargai. Keteraturan hidup perlu selalu dijaga. Hidup yang teratur adalah impian setiap insan. Menciptakan \& menjaga kehidupan yang harmonis adalah tugas manusia.

Manusia adalah makhluk Tuhan yang paling tinggi dibanding makhluk Tuhan lainnya. Manusia di anugerahi kemampuan untuk berpikir, kemampuan untuk memilah \& memilih mana yang baik \& mana yang buruk. Dengan kelebihan itulah manusia seharusnya mampu mengelola lingkungan dengan baik.
Tidak hanya lingkungan yang perlu dikelola dengan baik, kehidupan social manusiapun perlu dikelola dengan baik. Untuk itulah dibutuhkan sumber daya manusia yang berkualitas. Sumber daya yang berjiwa pemimpin, paling tidak untuk memimpin dirinya sendiri.

Kepemimpinan merupakan suatu topik bahasan yang menarik dan penting, karena sangat menentukan berlangsungnya suatu organisasi. Kepemimpinan itu esensinya adalah pertanggungjawaban. Masalah kepemimpinan masih sangat baik karena tiada habisnya untuk dibahas di sepanjang peradaban umat manusia. Terlebih pada zaman sekarang ini yang semakin buruk saja moral dan mentalnya. Ibaratnya, semakin sulit mencari pemimpin yang baik (good leader). Pemimpin yang baik sebenarnya pemimpin yang mau berkorban dan peduli untuk orang lain serta bersifat melayani. Tetapi, kenyataannya berbeda. Bila kita lihat sekarang para pemimpin kita, dari lapisan bawah sampai 
lapisan tertinggi, dari pusat hingga ke daerah daerah. Banyak pemimpin yang hadir dengan tanpa mencerminkan sosok pemimpin yang seharusnya, malah terlihat adanya pemimpinpemimpin yang jauh dari harapan rakyat, tidak peduli dengan nasib rakyat bawah, dan hampir tidak pernah berpikir untuk melayani masyarakat. Karena kepemimpinan mereka lebih dilandasi pada keinginan pribadi dan lebih mengutamakan kepentingan

Dengan berjiwa pemimpin manusia akan dapat mengelola diri, kelompok \& lingkungan dengan baik. Khususnya dalam penanggulangan masalah yang relatif pelik \& sulit. Disinilah dituntut kearifan seorang pemimpin dalam mengambil keputusan agar masalah dapat terselesaikan dengan baik.

Di RW 03 Kelurahan Ketawang Gede jumlah anggota PKKyang terdiri dari Ibu- ibu yang jumlahnya 30 orang dengan profesi $90 \%$ : wirausaha, 10\% Karyawan Swasta dan PNS usia antara 25 - 50 tahun dimana mereka selalu melakukan banyak kegiatan organisasi yang berhubungan dengan masyarakat, namun masih sedikit yaitu 3\% anggota PKK RW 03 yang mampu menjadi pemimpin/ ketua organisasi masyarakat dilingkungannya, salah satu bukti yang ada yaitu pada saat ada acara memperingati hari kemerdekaan 17 Agustus, salah anggota PKK RW 03 ditunjuk sebagai ketua panitia, hampir semua anggota menyatakan tidak bersedia,dengan alasan tidak bisa memimpin pada hal waktu itu sangat dibutuhkan untuk menyusun struktur organisasi kepantiaan, mengatur dan menyusun acara, mengkoordinir kegiatan. Dampaknya acara 17 agustus tidak ada ketua panitia, sehingga sebagai pengambil keputusan adalah semua anggota PKK RW 03 secara musyawarah mufakat dan memerlukan waktu yang lama serta adanya perdebatan setiap pengambilan keputusan karena menunggu pendapat dari 30 orang anggota PKK.

Politeknik Negeri Malang sebagai instrument bagian dari masyarakat yang merupakan lembaga institusi pendidikan bertugas memberikan pendidikan kepada masyarakat sebagai bentuk kepedulian sosial. Oleh karena itu dilakukan program pengabdian kepada masyarakat dengan materi: Bimbingan Dan Pelatihan Implementasi Kepemimpinan Untuk Pemberdayaan Ibu-Ibu PKK RW 03 Kelurahan Ketawang Gede Kota Malang.
Hasil dari kegiatan ini diharapkan mampu menjadi solusi permasalahan dengan harapan dapat membentuk jiwa kepemimpinan yang baik.

Sedikitnya wanita yang menjadi pemimpin, padahal jika wanita

berkesempatan memegang peranan sebagai pemimpin membawa dampak yang mengarah lebih baik bahwa permasalahan yang ada ditandai dengan tidak adanya kekosongan pimpinan pada organisasi. Dengan demikian, diperlukan wanita yang memiliki akses yang sama dalam mencapai sebuah peran kepemimpinan. Banyak masyarakat yang ingin wanita tampil sebagai pimpinan di lingkungannya hal tersebut khususnya ibu-ibu PKK RW 03 Kelurahan Ketawang Gede Kota Malang masih sedikit wanita yang mampu memimpin yaitu 3\%, sehingga penulis ingin informasi tambahan terkait hal tersebut dengan cara memberikan bimbingan dan pelatihan implementasi Kepemimpinan untuk pemberdayaan.

\section{KAJIAN LITERATUR}

\subsection{Hakikat Kepemimpinan}

Kepemimpinan adalah kemampuan seseorang mempengaruhi dan memotivasi orang lain untuk melakukan sesuatu sesuai tujuan bersama. Kepemimpinan meliputi proses mempengaruhi dalam menentukan tujuan organisasi, memotivasi perilaku pengikut untuk mencapai tujuan, mempengaruhi untuk memperbaiki kelompok dan budayanya. Sedangkan kekuasaan adalah kemampuan untuk mempengaruhi orang lain untuk mau melakukan apa yang diinginkan pihak lainnya. Fungsi pemimpin dalam suatu organisasi tidak dapat dibantah merupakan sesuatu fungsi yang sangat penting bagi keberadaan dan kemajuan organisasi yang bersangkutan. Pada dasarnya fungsi kepemimpinan memiliki 2 aspek yaitu:

a. Fungsi administrasi, yakni mengadakan formulasi kebijaksanakan administrasi dan menyediakan fasilitasnya.

b. Fungsi sebagai Top Mnajemen, yakni mengadakan planning, organizing, staffing, directing, commanding, controlling 


\subsection{Teori Kepemimpinan}

Beberapa teori tentang

kepemimpinan antara lain :

1. Teori Kepemimpinan Sifat (Trait Theory) Analisis ilmiah tentang kepemimpinan berangkat dari pemusatan perhatian pemimpin itu sendiri. Teori sifat berkembang pertama kali di Yunani Kuno dan Romawi yang beranggapan bahwa pemimpin itu dilahirkan, bukan diciptakan yang kemudian teori ini dikenal dengan "The Greatma Theory". Dalam perkembanganya, teori ini mendapat pengaruh dari aliran perilaku pemikir psikologi yang berpandangan bahwa sifat sifat kepemimpinan tidak seluruhnya dilahirkan akan tetapi juga dapat dicapai melalui pendidikan dan pengalaman. Sifat sifat itu antara lain : sifat fisik, mental, dan kepribadian. Keith Devis merumuskan 4 sifat umum yang berpengaruh terhadap keberhasilan kepemimpinan organisasi, antara lain :

1) Kecerdasan

Berdasarkan hasil penelitian, pemimpin yang mempunyai kecerdasan yang tinggi di atas kecerdasan rata - rata dari pengikutnya akan mempunyai kesempatan berhasil yang lebih tinggi pula. Karena pemimpin pada umumnya memiliki tingkat kecerdasan yang lebih tinggi dibandingkan dengan pengikutnya.

2) Kedewasaan dan Keluasan Hubungan Sosial

Umumnya di dalam melakukan interaksi sosial dengan lingkungan internal maupun eksternal, seorang pemimpin yang berhasil mempunyai emosi yang matang dan stabil. Hal ini membuat pemimpin tidak mudah panik dan goyah dalam mempertahankan pendirian yang diyakini kebenarannya.

3) Motivasi Diri dan Dorongan Berprestasi Seorang pemimpin yang berhasil umumnya memiliki motivasi diri yang tinggi serta dorongan untuk berprestasi. Dorongan yang kuat ini kemudian tercermin pada kinerja yang optimal, efektif dan efisien.

4) Sikap Hubungan Kemanusiaan

Adanya pengakuan terhadap harga diri dan kehormatan sehingga para

\author{
pengikutnya mampu berpihak \\ kepadanya
}

Teori Kepemimpinan Perilaku dan Situasi

Berdasarkan penelitian, perilaku seorang pemimpin yang mendasarkan teori ini memiliki kecendrungan kearah 2 hal.

a. Pertama yang disebut dengan Konsiderasi yaitu kecendrungan seorang pemimpin yang menggambarkan hubungan akrab dengan bawahan. Contoh gejala yang ada dalam hal ini seperti : membela bawahan, memberi masukan kepada bawahan dan bersedia berkonsultasi dengan bawahan.

b. Kedua disebut Struktur Inisiasi yaitu Kecendrungan seorang pemimpin yang memberikan batasan kepada bawahan. Contoh yang dapat dilihat, bawahan mendapat instruksi dalam pelaksanaan tugas, kapan, bagaimana pekerjaan dilakukan, dan hasil yang akan dicapai.Jadi, berdasarkan teori ini, seorang pemimpin yang baik adalah bagaimana seorang pemimpin yang memiliki perhatian yang tinggi kepada bawahan dan terhadap hasil yang tinggi pula.

c. Teori Kewibawaan Pemimpin Kewibawaan merupakan faktor penting dalam kehidupan kepemimpinan, sebab dengan faktor itu seorang pemimpin akan dapat mempengaruhi perilaku orang lain baik secara perorangan maupun kelompok sehingga orang tersebut bersedia untuk melakukan apa yang dikehendaki oleh pemimpin.

d. Teori Kepemimpinan Situasi

Seorang pemimpin harus merupakan seorang pendiagnosa yang baik dan harus bersifat fleksibel, sesuai dengan perkembangan dan tingkat kedewasaan bawahan.

e. Teori Kelompok Agar tujuan kelompok (organisasi) dapat tercapai, harus ada pertukaran yang positif antara pemimpin dengan pengikutnya

\subsection{Gaya Kepemimpinan}

Gaya kepemimpinan adalah cara seorang pemimpan bersikap, berkomunikasi, 
dan berinteraksi dengan orang lain dalam mempengaruhi orang untuk melakukan sesuatu. Gaya tersebut bisa berbeda - beda atas dasar motivasi, kuasa ataupun orientasi terhadap tugas atau orang tertentu. Berikut jenis jenis gaya kepemimpinan tranformasional :

a. Otokratis

Kepemimpinan seperti ini menggunakan metode pendekatan kekuasaan dalam mencapai keputusan dan pengembangan strukturnya. Kekuasaan sangat dominan digunakan. Memusatkan kekuasaan dan pengambilan keputusan bagi dirinya sendiri, dan menata situasi kerja yang rumit bagi pegawai sehingga mau melakukan apa saja yang diperintahkan. Kepemimpinan ini pada umumnya negatif, yang berdasarkan atas ancaman dan hukuman. Meskipun demikian, ada juga beberapa manfaatnya antaranya memungkinkan pengambilan keputusan dengan cepat serta memungkinkan pendayagunaan pegawai yang kurang kompeten.

b. Partisipasif

Lebih banyak mendesentrelisasikan wewenang yang dimilikinya sehingga keputusan yang diambil tidak bersifat sepihak.

c. Demokrasi

Ditandai adanya suatu struktur yang pengembangannya menggunakan pendekatan pengambilan keputusan yang kooperatif. Di bawah kepemimpinan pemimpin yang demokrasis cenderung bermoral tinggi dapat bekerjasama, mengutamakan mutu kerja dan dapat mengarahkan diri sendiri.

d. Kendali Bebas

Pemimpin memberikan kekuasaan penuh terhadap bawaan, strukturorganisasi bersifat longgar dan pemimpin bersifat pasif. Yaitu Pemimpin menghindari kuasa dan tanggung - jawab, kemudian menggantungkannya kepada kelompok baik dalam menetapkan tujuan dan menanggulangi masalahnya sendiri.

\section{METODE}

Metode yang digunakan dalam tulisan ini adalah: a) Alih Pengetahuan: Bentuk Alih pengetahuan/pendidikan dan pelatihan diadakan secara singkat dengan materi sesuai dengan kebutuhan para peserta yaitu teori kepemimpinan. b) Diskusi atau tanya jawab: Kegiatan ini dilakukan untuk mengetahui apakah materi telah dikuasai oleh peserta. Selain itu juga untuk memberi kesempatan pada peserta untuk menanyakan hal-hal yang belum dimengerti. c) Pembahasan Masalah/ Kasus: Dengan kegiatan ini peserta dapat mengetahui apa saja teori dan jenis jenis kepemimpinan dalam organisasi.

\section{HASIL DAN PEMBAHASAN}

Hasil dari penelitian ini dapat dilihat dalam Gambar 1.

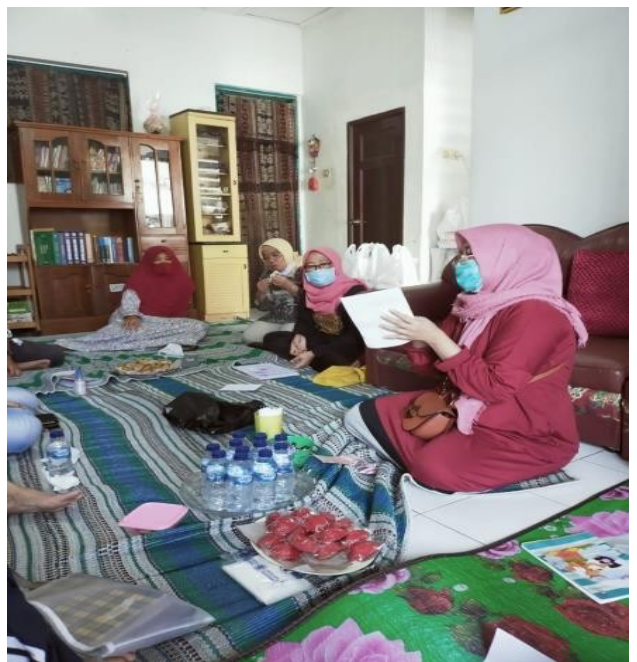

Gambar 1. Penyampaian Materi

Pada kegiatan ini dapa dilihat bahwa minat dan semangat para peserta dalam mengikuti pengabdian sangat besar sekali, sehingga mempermudah dalam proses belajar mengajar dan pemberian motivasi ,menyediakan tempat dan fasilitas yang memadai meskipun dalam kondisi yang sederhana.

Demikian juga pada kegiatan diskusi atau tanya jawab, dapat dilihat pada Gambar 2. 


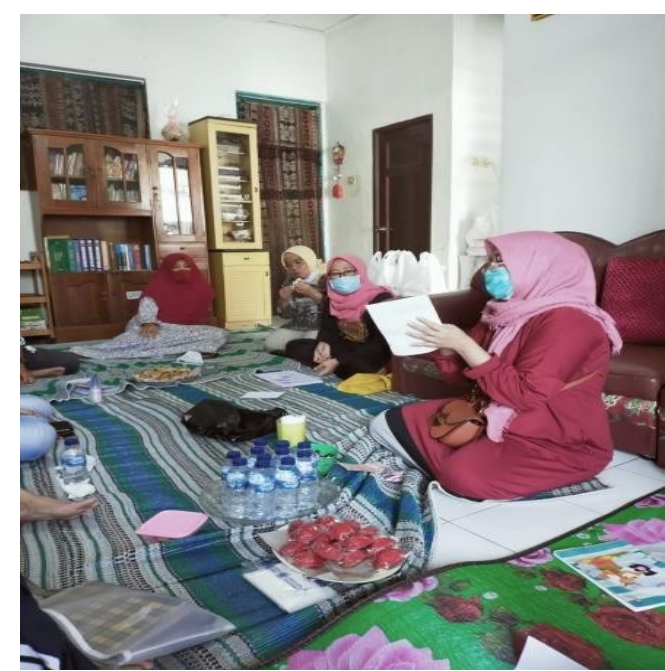

Gambar 2. Diskusi dan Tanya Jawab

Peserta Pengabdian Masyarakat ini mempunyai keinginan yang cukup besar untuk menambah pengetahuan dan ketrampilan untuk memiliki jiwa kepemimpinan yang baik, ditunjukkan dengan jumlah peserta yang hadir 30 orang dan $90 \%$ peserta mengajukan pertanyaan serta $100 \%$ peserta dapat menerapkan menjadi pemimpin yang baik dalam organisasi. Setelah melakukan diskusi terkait dengan kepemimpinan, peserta diberikan kasus untuk dipecahkan kemudian dibahas bersama dengan pemateri, seperti pada Gambar 3.

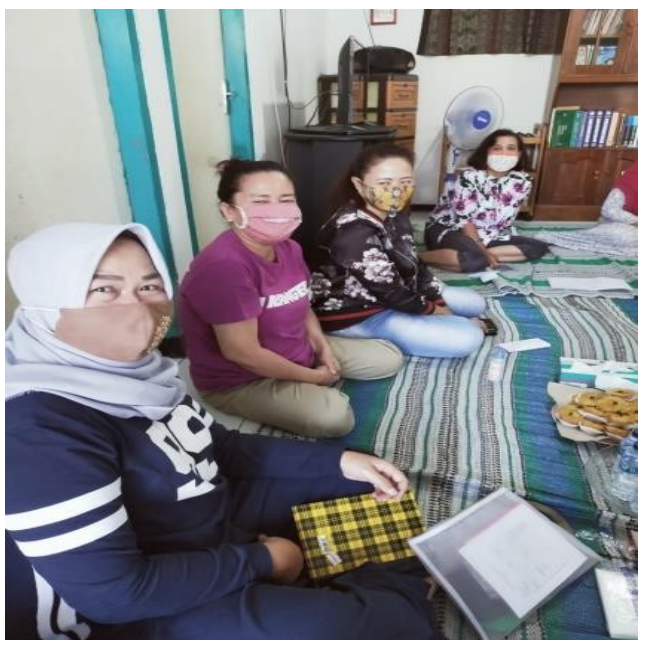

Gambar 3. Pembahasan Kasus

Pada kegiatan ini, peserta menyampaikan dan menyimak dengan baik pembahasan yang disampaikan oleh pemateri. Berdasarkan hasil observasi selama kegiatan pengabdian berlangsung dapat dinilai bahwa $90 \%$ materi dapat diserap ( dimengerti dan dipahami ) oleh peserta Pengabdian Masyarakat. Hal ini ditunjukkan dengan sebagian besar peserta yaitu $90 \%$ dari 30 peserta yaitu 27 orang, memberikan pertanyaan tentang kepemimpinan yang baik.

\section{KESIMPULAN}

Setelah dilaksanakannya kegiatan Pengabdian pada Masyarakat ini maka dapat diambil kesimpulan :

1. Kegiatan pengabdian dan pengetahuan serta aplikasi yang sangat penting dalam rangka usaha untuk memperoleh tambahan pengetahuan dan wawasan tentang informasi kiat menjadi pemimpin berjalan dengan baik.

2. Partisipasi peserta sangat besar hal ini ditunjukkan dengan hadirnya 30 orang peserta dari total jumlah anggota atau PKK RW 03 Kelurahan Ketawang Gede Kecamatan Lowokwaru Kota Malang yang aktif 30 orang yang ikut serta dalam pengabdian ini. Berdasarkan hasil observasi selama kegiatan pengabdian berlangsung dapat dinilai bahwa pengabdian yang diberikan mudah dikuasai oleh peserta, karena materinya bersifat praktis, hanya diperlukan ketekunan dan kesabaran

\section{DAFTAR PUSTAKA}

Keraf, Sony, 2002, Etika Lingkungan, Jakarta, Penerbit Buku Kompas

Kotler, Philip, 2003, Marketing

Management, Prentice Hall, Pearson, Educational International.

Pasaribu, R, 2008, Teori Etika Praktis, Medan: Pieter

Pudjowiyatna, 2006, Etika Filsafat Tingkah Laku, Bina Aksara, Jakarta Puspoprodjo, W, 2010, Filsafat Moral, Bandung: Remaja Karya

Prately, Peter, 2007, Etika Bisnis, Yogyakarta, Andi Of 